\title{
PERUBAHAN KOMPOSISI METIL ESTER AKIBAT KERUSAKAN PANAS PADA METIL ESTER SULFONAT DARI JARAK PAGAR
}

\author{
Sri Hidayati \\ Jurusan Teknologi Hasil Pertanian, Fakultas Pertanian, Universitas Lampung \\ Jl. Sumantri Brojonegoro No. 1 Bandar Lampung \\ Email: hidayati_thp@unila.ac.id
}

\begin{abstract}
Surfactant is a surface-active agent that can be produced by a chemical or biochemical synthesis. The most widely used anionic surfactant in surfactant flooding is linier alkyl benzene sulfonate (LAS) synthesized from petroleum material. The weaknesses of petroleum based surfactant are: it is made from nonrenewable resources, has very poor detergency in hard water and naturally are difficult to be degraded. These problems can be overcome by producing methyl ester sulfonate (MES) surfactant made from natural resources, such jatropha oil es methyl ester. Temperature is the important factor that should be performed in MES stability. The purpose of this research is to investigate the sulfonate group caused by temperature and degradation time. The result of thermal degradation tests of Methyl Ester Sulfonates showed that at temperature of $150{ }^{\circ} \mathrm{C}$ during 72 hours influenced the degradation of sulfonate group. It was indicated by decreasing peak of sulfonate formed at the wave number of $1250-1150 \mathrm{~cm}^{-1}$. The increased of temperature showed decreased ability of surfactant to stabilized of emulsion and surface tension.
\end{abstract}

Keywords: methyl ester sulfonates, thermal degradation

\section{PENDAHULUAN}

Surfaktan (Surface Active Agent) adalah suatu bahan yang dapat mengubah atau memodifikasi tegangan permukaan dan antarmuka antara fluida yang tidak saling larut ${ }^{[1-4]}$ atau molekul yang mengadsorbsi molekul lain pada antarmuka dua zat ${ }^{[5]}$. Metil ester sulfonat (MES) adalah salah satu surfaktan anionik yang dibuat melalui proses sulfonasi dengan menggunakan bahan baku dari minyak nabati maupun hewani. MES memiliki keunggulan dibandingkan dengan surfaktan yang dibuat dari minyak bumi (petroleum) yaitu sifatnya renewable, lebih ramah lingkungan karena mudah didegradasi oleh bakteri, memiliki ketahanan terhadap kesadahan dan suhu tinggi serta memiliki pembusaan yang rendah ${ }^{[6-8]}$.

Salah satu faktor penting dalam memanfaatkan surfaktan untuk Enhanced Oil Recovery (EOR) adalah kestabilannya terhadap panas. Dimana pada waktu pemanfaatan di sumur, sistem aktivasi surfaktan dapat rusak oleh tingginya suhu di dalam reservoir terutama dalam waktu yang cukup lama ${ }^{[9]}$. Secara umum, surfaktan dari golongan sulfonat lebih tahan terhadap suhu dibandingkan dengan surfaktan dari golongan sulfat ${ }^{[9,10]}$. Ziegler and Handy ${ }^{[11]}$ melaporkan bahwa penggunaan suhu $200{ }^{\circ} \mathrm{C}$ pada surfaktan jenis Alfa Olefin Sulfonat menyebabkan surfaktan sudah terdegradasi dengan cepat. Beberapa sumur minyak memiliki suhu lebih besar dari $85^{\circ} \mathrm{C}$. Surfaktan jenis petroleum sulfonat, alkil sulfonat, atau alkilaril sulfonat, masih efektif digunakan pada sumur dengan suhu tidak lebih dari $120 \mathrm{~F}$, lebih tinggi suhu yang digunakan akan mempengaruhi kinerja surfaktan terutama kemampuannya untuk menurunkan tegangan permukaan dan stabilitas emulsi. Tujuan penelitian ini adalah untuk mengetahui pengaruh suhu dan lama waktu pemanasan pada degradasi panas terhadap kinerja MES dari jarak pagar yaitu tegangan permukaan dan stabilitas emulsi serta melihat hasil pemecahan fraksi-fraksi metil ester akibat suhu tinggi menggunakan Fourier Transform Infrared (FTIR) dan Kromatografi Gas. 


\section{METODOLOGI PENELITIAN}

\begin{abstract}
Alat dan Bahan
Peralatan yang digunakan dalam proses pembuatan MES adalah seperangkat reaktor sulfonasi, sentrifus, rotor penggerak, alat timbang, dan alat analisis uji kimia. Bahan yang digunakan untuk penelitian adalah: ester asam lemak jarak pagar, $\mathrm{NaHSO}_{3}$, metanol, dan bahan kimia untuk analisis.
\end{abstract}

Peralatan untuk membuat MES terdiri dari rangkaian alat sulfonasi yang terdiri dari labu tiga leher $500 \mathrm{~mL}$, termometer, hot plate yang dilengkapi magnetic stirrer, motor pengaduk, dan kondensor, neraca analitik, alat gelas, oven, sentrifuge dan $\mathrm{pH}$-meter. Peralatan untuk analisis sampel adalah spinning drop tensiometer, syringe $(\mu \mathrm{m})$, neraca analitik, piknometer, refraktometer, FTIR, dan kromatografi gas.

\section{Pelaksanaan Percobaan}

\section{Prosedur Pembuatan Surfaktan MES dari Metil Ester jarak pagar}

MES dibuat melalui beberapa tahap yaitu sulfonasi, pengendapan, pemurnian, penguapan metanol dan penetralan. Reaksi sulfonasi antara metil ester dengan reaktan $\mathrm{NaHSO}_{3}$ merupakan tahapan utama proses pembuatan MES. Kondisi proses yang digunakan untuk membuat MES merujuk pada kondisi terbaik ${ }^{[12]}$ dengan perbandingan mol metil ester dan reaktan $\mathrm{NaHSO}_{3}$ adalah $1: 1,5$; suhu reaksi 100 ${ }^{\circ} \mathrm{C}$ dan lama reaksi 4,5 jam. Pengendapan dilakukan selama 24 jam. Pemurnian dilakukan dengan menambahkan metanol. Metanol ditambahkan sebanyak $30 \%(\mathrm{v} / \mathrm{v})$ pada suhu 50 ${ }^{\circ} \mathrm{C}$ dan direaksikan selama 1,5 jam. Setelah reaksi selesai, suhu larutan dinaikkan hingga mencapai $70-80{ }^{\circ} \mathrm{C}$ selama 10 menit, untuk menguapkan metanol dari larutan. Metanol yang menguap kemudian dikondensasi dan ditampung dalam erlenmeyer. Proses selanjutnya adalah penetralan menggunakan $\mathrm{NaOH} 20 \%$. MES yang telah dinetralkan kemudian dipanaskan hingga mencapai suhu $55{ }^{\circ} \mathrm{C}$ sambil diaduk dengan menggunakan pengaduk selama 30 menit. Setelah proses pengadukan dan pemanasan selesai, MES kemudian dipindahkan ke dalam wadah yang terbuat dari kaca dan ditutup. Diagram alir pembuatan dan pemurnian MES disajikan pada Gambar 1.

\section{Prosedur Kerja}

Sampel (MES) dimasukkan ke dalam tabung tertutup, masing-masing $100 \mathrm{~mL}$ dan dipanaskan ke dalam oven dengan suhu $120^{\circ} \mathrm{C}$ dan $150{ }^{\circ} \mathrm{C}$ selama 8,48 dan 72 jam. Sampel kemudian dianalisis perubahan gugus sulfonat dan hasil degradasi dengan menggunakan FTIR (spektroskopi Perkin Elmer 1600 series) yang sudah dikoneksikan dengan komputer Perkin Elmer 7300 profesional computer. Data dari FTIR diperoleh dengan menggunakan bilangan gelombang dari 4000 sampai $400 \mathrm{~cm}^{-1}$. Perubahan komposisi kimia diuji dengan menggunakan kromatografi gas dan dilakukan uji kinerja MES yaitu kestabilan emulsi (modifikasi ASTM D 1436, 2001) $^{[13]}$ dan tegangan permukaan menggunakan $d u$ Nouy. Data disajikan dalam bentuk deskriptif.

\section{Pengamatan}

\section{Analisis Metil Ester Menggunakan Kromatografi Gas ${ }^{[14]}$}

Sebanyak $2 \mathrm{~g}$ minyak ditambahkan ke dalam labu didih, kemudian ditambahkan 6-8 $\mathrm{mL}$ $\mathrm{NaOH}$ dalam metanol, dipanaskan sampai tersabunkan lebih kurang 15 menit dengan pendingin balik. Selanjutnya ditambahkan 10 $\mathrm{mL} \mathrm{BF}_{3}$ dan dipanaskan kira-kira dua menit. Dalam keadaan panas ditambahkan $5 \mathrm{~mL}$ heptana atau n-heksana, kemudian dikocok dan ditambahkan larutan $\mathrm{NaCl}$ jenuh. Larutan akan terpisah menjadi dua bagian. Bagian atas akan dipindahkan ke dalam tabung reaksi yang sebelumnya telah diberi $1 \mathrm{~g} \mathrm{Na}_{2} \mathrm{SO}_{4}$. Larutan tersebut siap diinjeksikan pada suhu detektor $230^{\circ} \mathrm{C}$, suhu injektor $225^{\circ} \mathrm{C}$, suhu awal $70{ }^{\circ} \mathrm{C}$, pada suhu awal $=2$ menit, menggunakan glass coloumn dengan panjang 2 meter dan diameter $2 \mathrm{~mm}$, gas pembawa adalah helium dan fasa diam dietilen glikol suksinat. Jenis detektor yang digunakan adalah jenis FID (Flame Ionization Detector). 


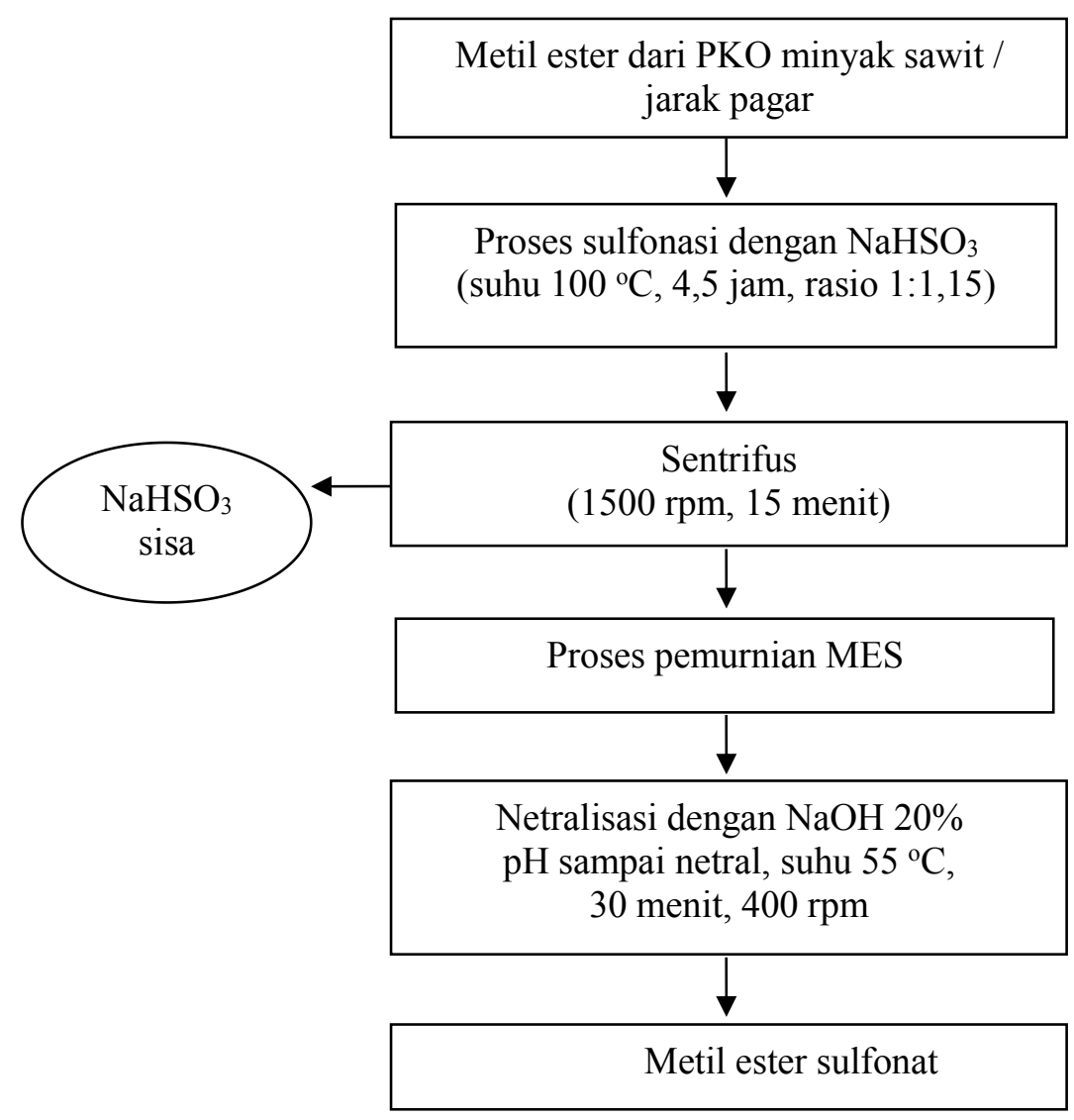

Gambar 1. Diagram alir proses produksi MES dari ester asamdari minyak sawit dan jarak pagar dengan menggunakan $\mathrm{NaHSO}_{3}$.

\section{Pengukuran Gugus Sulfonat Menggunakan Fourier Transform Infrared (FTIR) (ASTM D2357-74) ${ }^{[13]}$}

Sebanyak $3 \mathrm{~g}$ sampel diteteskan di dalam pelet $\mathrm{KBr}$ pada kondisi ruang kemudian diukur pada bilangan gelombang antara $400-3300 \mathrm{~cm}^{-1}$ menggunakan spektrofotometer Infrared. Gugus sulfonat dihasilkan pada bilangan gelombang $1235-1070 \mathrm{~cm}^{-1}$.

\section{Tegangan Permukaan Metode Du Nuoy}

Larutan yang digunakan adalah aquades dan larutan surfaktan sebanyak 10\%. Larutan contoh dimasukkan ke dalam gelas dan diletakkan pada dudukan (platform) pada tensiometer. Suhu cairan pada sampel diukur dan dicatat. Selanjutnya cincin platinum dicelupkan ke dalam sampel tersebut (lingkaran cincin tercelup 3-5 $\mathrm{mm}$ dibawah permukaan cairan). Skala vernier tensiometer diset pada posisi nol dan jarum petunjuk harus berada pada garis berimpit dengan garis pada kaca. Selanjutnya platform diturunkan secara perlahan, dan pada saat yang bersamaan skup kanan diputar sampai film cairan tepat putus. Pada saat ini dilakukan pembacaan skala. Pengujian dilakukan minimal dua kali pengulangan kemudian dibandingkan nilai tegangan permukaan antara sebelum dan sesudah ditambahkan surfaktan.

\section{Stabilitas Emulsi}

Kestabilan emulsi diukur antara air dengan xylene. Xylene dengan air dicampur dengan perbandingan 6:4. Campuran kemudian dikocok selama 5 menit menggunakan vortex mixer. Pemisahan emulsi antar xylene dengan air diukur berdasarkan lamanya pemisahan antar fasa. Konsentrasi surfaktan yang ditambahkan adalah $1 \mathrm{~mL}$. Lamanya pemisahan antar fasa sebelum ditambahkan surfaktan dibandingkan dengan sesudah ditambahkan surfaktan ${ }^{[13]}$. 


\section{HASIL DAN PEMBAHASAN}

\section{Pengaruh Suhu dan Lama Pemanasan terhadap Tegangan Permukaan (IFT) MES Jarak Pagar}

Tegangan permukaan $(\gamma)$ adalah besar gaya $(F$ dalam Newton) yang dialami permukaan zat cair persatuan panjang (L dalam meter). Dirumuskan dalam persamaan $\gamma=\mathrm{F} / 2 \mathrm{~L}$. Permukaan air teregang akibat adanya gaya tarik antar molekul air di permukaan. Dengan kata lain terdapat gaya kohesi pada molekulmolekul air di permukaan. Gaya kohesi ini selalu berusaha untuk memperkecil luas permukaan zat air. Air yang berada dalam keadaan ini dikatakan memiliki tegangan permukaan. Hal yang berkaitan dengan kohesi adalah tegangan permukaan air yaitu ukuran seberapa sulitnya permukaan suatu cairan diregang atau dipecahkan. Air memiliki tegangan permukaan yang besar yang disebabkan oleh kuatnya sifat kohesi antar molekul-molekul air. Hal ini dapat diamati saat sejumlah kecil air ditempatkan dalam sebuah permukaan yang tak dapat terbasahi atau terlarutkan (non-soluble), air tersebut akan berkumpul sebagai sebuah tetesan. Dengan kata lain, terdapat gaya kohesi pada molekulmolekul air di permukaan. Gaya kohesi ini selalu berusaha untuk memperkecil luas permukaan zat air. Air yang berada dalam keadaan ini dikatakan memiliki tegangan permukaan ${ }^{[15]}$. Hasil penelitian menunjukkan bahwa suhu dan lama pemanasan MES meningkatkan nilai tegangan permukaan dari MES berbasis jarak pagar (Gambar 2).

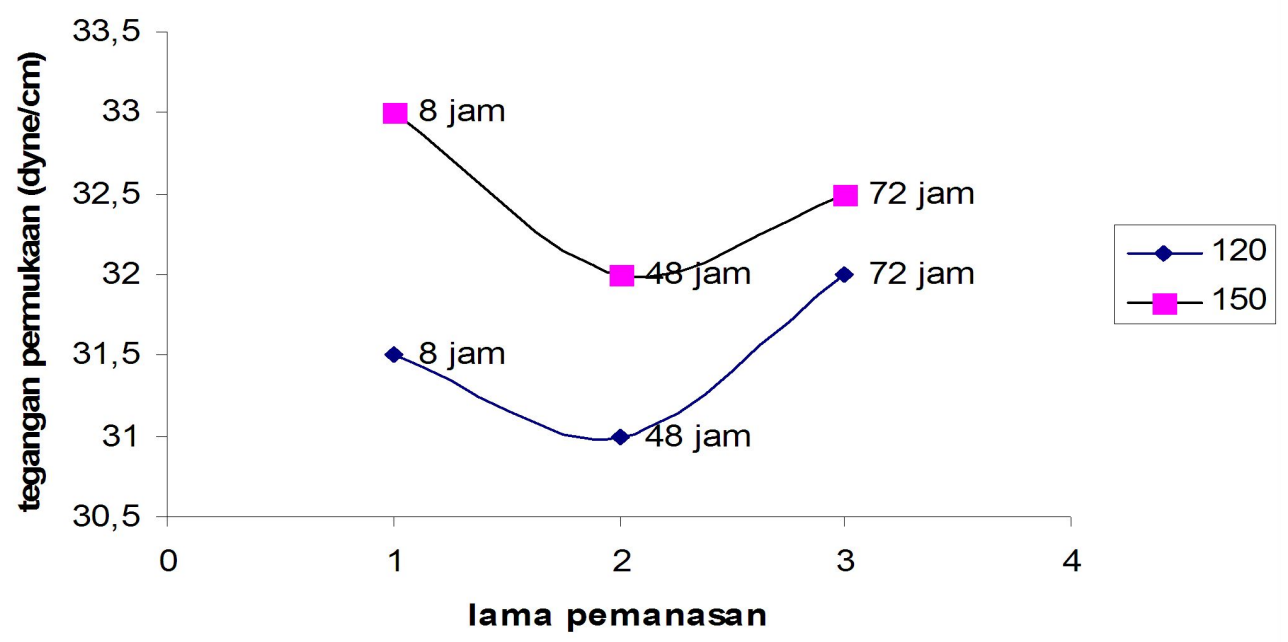

Gambar 2. Pengaruh suhu dan lama pemanasan terhadap tegangan permukaan MES dari jarak pagar.

Suhu dan waktu pemanasan yang tinggi menyebabkan laju reaksi berlebihan yang menyebabkan degradasi MES yang menghasilkan garam disalt yang akan mengurangi kamampuan kinerja MES ${ }^{[16]}$. Laju reaksi berkaitan erat dengan terjadinya reaksi kimia dari suatu zat dalam membentuk hasil reaksi. Reaksi kimia terjadi akibat adanya tumbukan antara molekul dari zat yang bereaksi. Untuk menghasilkan suatu tumbukan diperlukan energi kinetik yang lebih besar dibandingkan dengan energi aktivasi.

\section{Pengaruh Suhu dan Lama Pemanasan terhadap Stabilitas Emulsi MES Jarak Pagar}

Hasil penelitian menunjukkan bahwa semakin lama waktu pemanasan menurunkan stabilitas emulsi (Gambar 3). Sesuai dengan penelitian Hidayati ${ }^{[12]}$ bahwa MES dari PKO menunjukkan penurunan stabilitas emulsi dengan semakin tinggi suhu dan lama pemanasan sehingga menurunkan zat aktif dari gugus sulfonat. Gugus sulfonat merupakan senyawa aktif penurun tegangan antar muka (IFT) dan tegangan permukaan 
serta mampu meningkatkan stabilitas emulsi. Emulsi terjadi apabila dua fluida tercampur dan salah satu fluida terdispersi ke dalam fluida yang lainnya. Penambahan surfaktan pada suatu sistem emulsi bertujuan untuk meningkatkan kestabilan dispersi fasa-fasa dengan cara mengurangi tegangan antar muka. Surfaktan yang bertindak sebagai emulsifier akan membentuk lapisan tipis yang akan menyelimuti partikel-partikel teremulsi dan mencegah partikel tersebut bergabung kembali dengan partikel sejenisnya ${ }^{[17]}$.

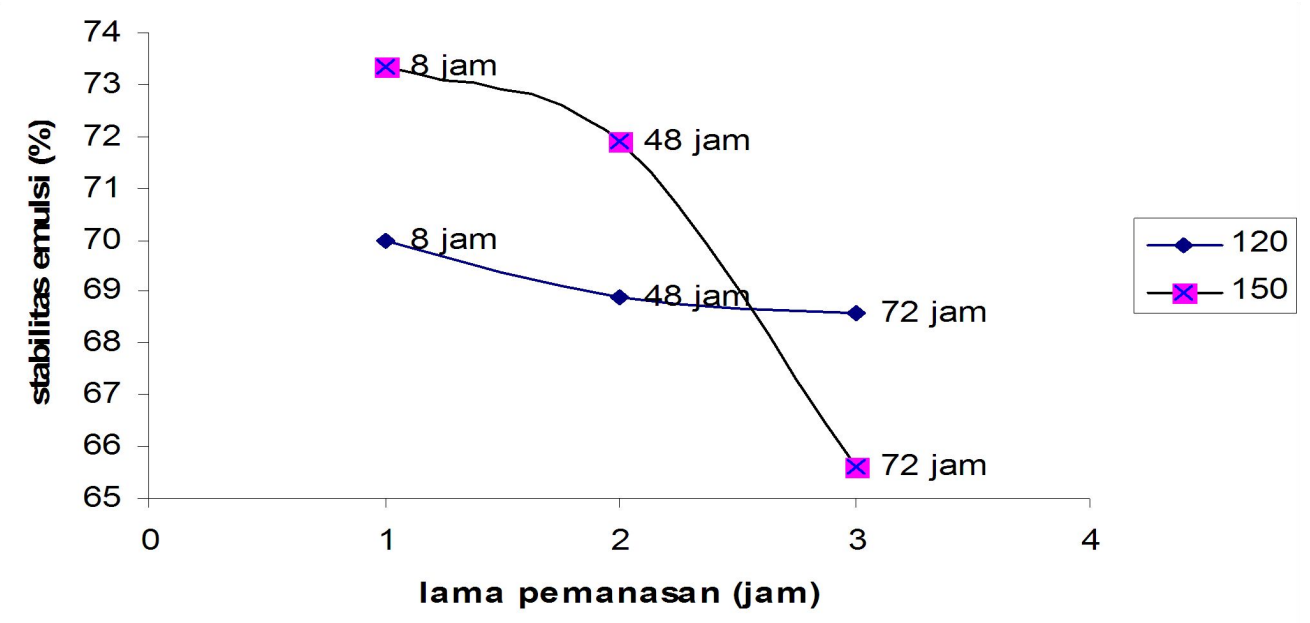

Gambar 3. Pengaruh suhu dan lama pemanasan terhadap stabilitas emulsi MES jarak.

Penambahan surfaktan dapat menstabilkan suatu emulsi karena surfaktan menurunkan tegangan permukaan secara bertahap. Adanya penurunan tegangan permukaan secara bertahap akan menurunkan energi bebas yang diperlukan untuk pembentukan emulsi menjadi semakin minimal. Artinya emulsi akan menjadi stabil bila dilakukan penambahan surfaktan yang berfungsi untuk menurunkan energi bebas pembentukan emulsi semaksimal mungkin. Semakin rendah energi bebas pembentukan emulsi maka emulsi akan semakin mudah terbentuk. Stabilitas emulsi terjadi ketika sistem dapat mempertahankan tetesan fase terdispersi, yaitu ketika penggabungan antar tetesan dapat dicegah oleh energi penghalang yang cukup besar ${ }^{[18]}$.

Tegangan permukaan menurun karena terjadi adsorpsi oleh surfaktan pada permukaan cairan dengan bagian ujung yang polar berada di air dan ujung hidrokarbon pada minyak. Akibatnya kemampuan surfaktan untuk mempertahankan pengikatan gugus polar pada bagian hidrofilik dan gugus non polar pada bagian hidrofobik akan berkurang sehingga molekul yang larut dalam air akan bergabung kembali (coalecense) dan terjadi proses pemisahan karena emulsi tidak stabi ${ }^{[18]}$. Peningkatan suhu dan lama reaksi dalam pembuatan MES minyak jarak pagar menyebabkan kerusakan fungsi surfaktan sebagai emusifier yang ditunjukkan oleh tingkat stabilitas emulsi yang rendah.

\section{Pengaruh Suhu dan Lama Pemanasan terhadap Stabilitas Gugus Sulfonat MES dari Jarak Pagar}

Pada surfaktan untuk Enhanced Oil Recovery (EOR), salah satu faktor yang penting adalah kestabilan terhadap panas. Sistem aktivasi surfaktan dapat rusak oleh tingginya suhu di dalam reservoir terutama dalam waktu yang cukup lama ${ }^{[9]}$. Secara umum, kestabilan emulsi surfaktan golongan sulfonat lebih tinggi dibandingkan dari golongan sulfat. Hasil pengujian pengaruh suhu dan lama pemanasan terhadap perubahan gugus sulfonat menunjukkan bahwa semakin tinggi suhu dan lama pemanasan akan berpengaruh terhadap kerusakan gugus sulfonat surfaktan ditandai dengan puncak gugus sulfonat yang mengecil. Hal ini diduga karena semakin tinggi suhu dengan lama waktu akan merusak gugus reaktif hidrofobik dan hidrofilik memisah terutama terjadi pengurangan pada gugus $\mathrm{S}=\mathrm{O}$. Peesok et $a{ }^{[19]}$ menyatakan bahwa gugus sulfonat ionik dideteksi pada 
bilangan gelombang $1250-1150 \mathrm{~cm}^{-1}$ dan $1075-1000 \mathrm{~cm}^{-1}$, sedang dari ASTM $(2001)^{[13]}$ (D 2357-74) gugus sulfonat dihasilkan pada bilangan gelombang 1235 sampai $1176 \mathrm{~cm}^{-1}$. MES dari metil ester dari jarak pagar yang tidak dipanaskan, gugus sulfonat diperlihatkan pada bilangan gelombang 1235 sampai $1172 \mathrm{~cm}^{-1}, \quad \mathrm{~S}=\mathrm{O}$ pada bilangan gelombang $1029,1 \mathrm{~cm}^{-1}$ dan golongan alkohol pada bilangan gelombang $3600-3200 \mathrm{~cm}^{-1}$ (Gambar 4).

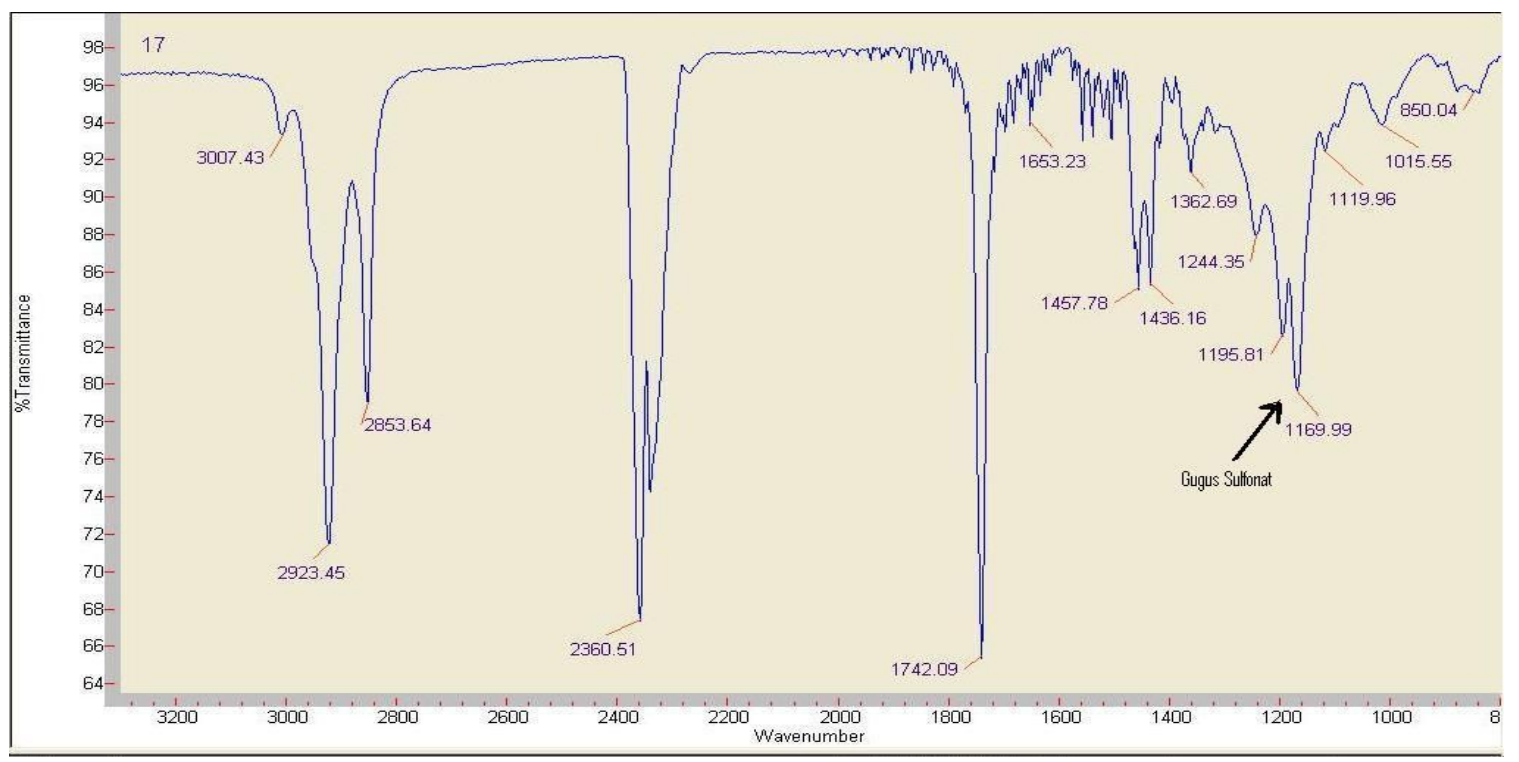

Gambar 4. Analisis gugus sulfonat pada MES minyak jarak pagar (Jatropha Curcas L.) yang diuji dengan menggunakan FTIR.

Hasil analisis gugus sulfonat pada MES dari metil ester jarak pagar menunjukkan bahwa MES tersebut memiliki ketahanan terhadap panas hingga mencapai suhu $180{ }^{\circ} \mathrm{C}$ dengan waktu dari 8, 48 dan 72 jam. (Gambar 5, 6, 7, 8, 9 dan 10). Pemanasan pada suhu $180{ }^{\circ} \mathrm{C}$ selama 8 jam memiliki pola yang sama dengan pola spektrum pada pemanasan suhu $100{ }^{\circ} \mathrm{C}$ selama 8,48 , jam dan 72 jam dan pemanasan pada suhu $150{ }^{\circ} \mathrm{C}$ selama 8 jam, 48 dan 72 jam tetapi pada pemanasan pada suhu $180^{\circ} \mathrm{C}$ selama 72 jam memiliki pola yang berbeda dengan ketiga pola diatas. Perlakuan pemanasan pada suhu $180{ }^{\circ} \mathrm{C}$ menyebabkan surfaktan MES mengalami kerusakan. Hal ini ditandai dengan mulai berkurangnya tinggi puncak gugus sulfonat dan gugus lain seperti aldehid (pada bilangan gelombang $2855 \mathrm{~cm}^{-1}$ ), gugus $\mathrm{C}=\mathrm{O}$ pada bilangan gelombang $1740-1720 \mathrm{~cm}^{-1}$ yang merupakan alifatik aldehid ${ }^{[20]}$ dan terjadi puncak-puncak yang lebih kecil hasil dari degradasi termal. Spektrum cis region pada bilangan gelombang $3017-3000 \mathrm{~cm}^{-1}$ mulai menurun, hal ini berhubungan dengan terbentuknya hidroperoksida dan terbentuk trans region pada bilangan gelombang 970 $\mathrm{cm}^{-1}$ yang menunjukkan hasil proses oksidasi $^{[21]}$. Samuelsson dan Johanssen ${ }^{[22]}$, menyatakan bahwa pada proses oksidasi linoleat dimulai dari terbentuknya radikal karbon pada pusat yang menyebabkan bentuk cis berubah menjadi trans, kemudian dengan adanya gugus $\mathrm{O}$ akan membentuk hidroperoksida yang bersifat tidak stabil. 


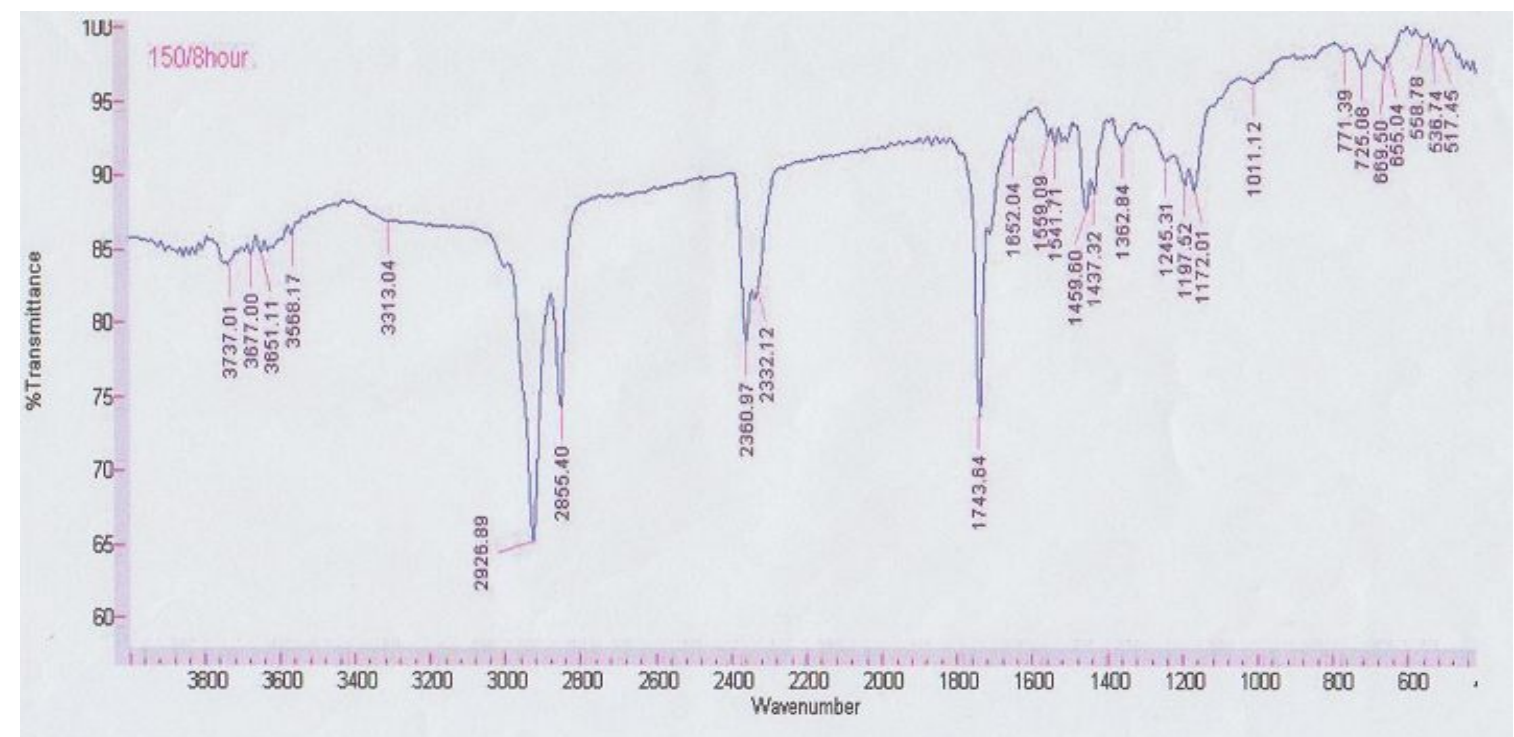

Gambar 5. Analisis gugus sulfonat pada hasil degradasi MES dari metil ester jarak pagar yang dipanaskan pada suhu $150^{\circ} \mathrm{C}$ selama 8 jam yang diuji dengan menggunakan FTIR.

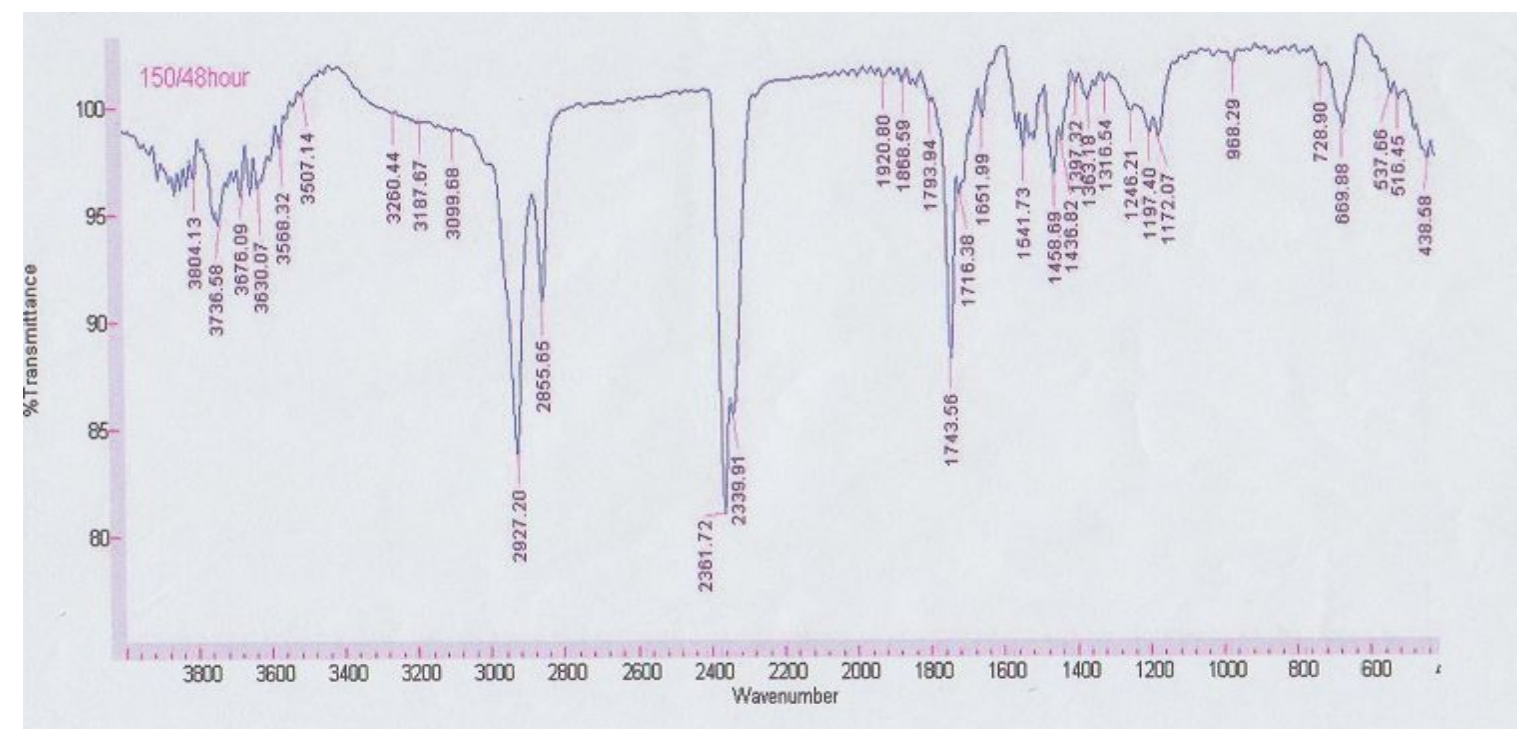

Gambar 6. Analisis gugus sulfonat pada hasil degradasi MES dari metil ester jarak pagar yang dipanaskan pada suhu $150^{\circ} \mathrm{C}$ selama 48 jam yang diuji dengan menggunakan FTIR. 


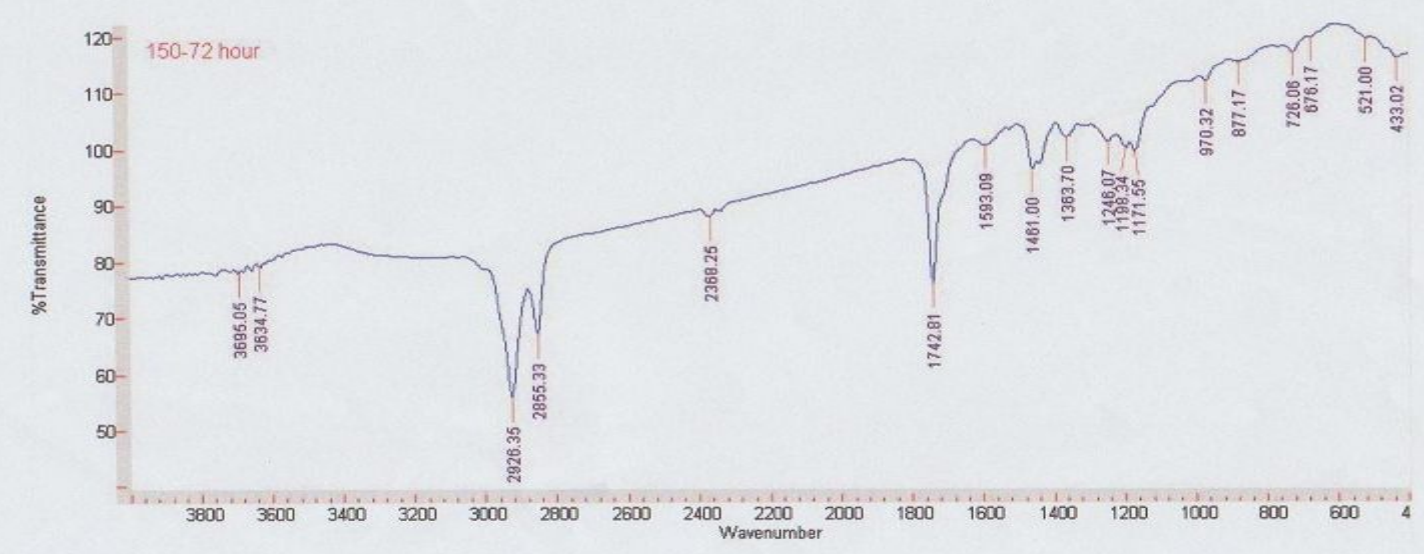

Gambar 7. Analisis gugus sulfonat pada hasil degradasi MES dari metil ester jarak pagar yang dipanaskan pada suhu $150^{\circ} \mathrm{C}$ selama 72 jam yang diuji dengan menggunakan FTIR.

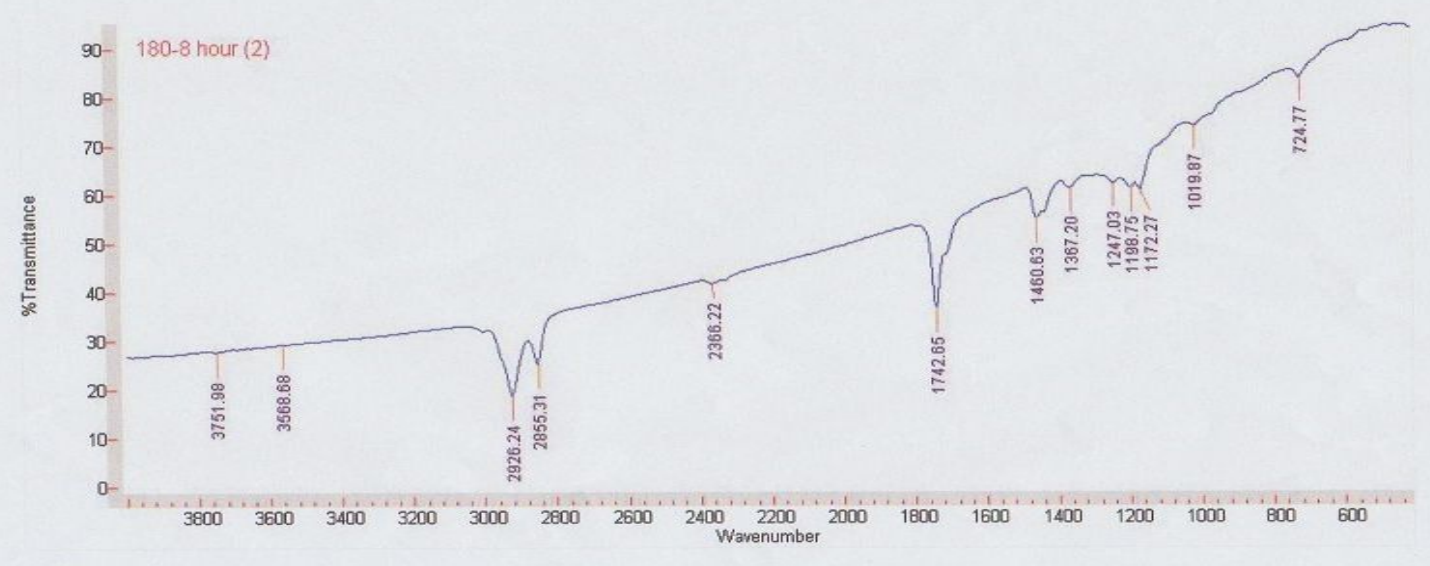

Gambar 8. Analisis gugus sulfonat pada hasil degradasi MES dari metil ester jarak pagar yang dipanaskan pada suhu $180^{\circ} \mathrm{C}$ selama 8 jam yang diuji dengan menggunakan FTIR.

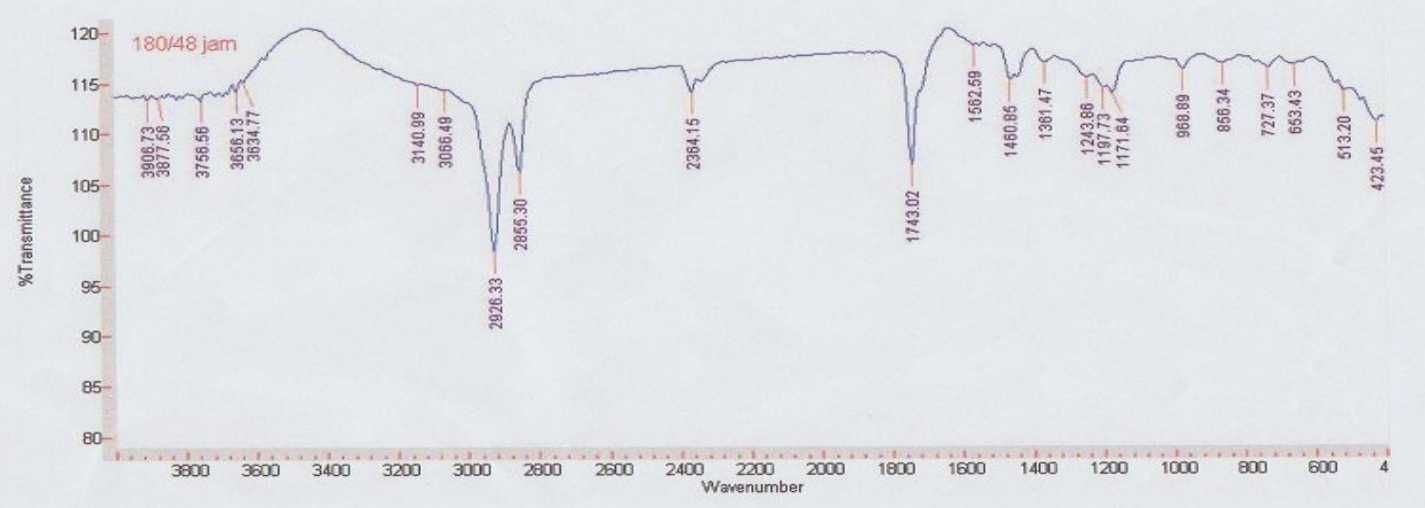

Gambar 9. Analisis gugus sulfonat pada hasil degradasi MES dari metil ester jarak pagar yang dipanaskan pada suhu $180^{\circ} \mathrm{C}$ selama 48 jam yang diuji dengan menggunakan FTIR. 


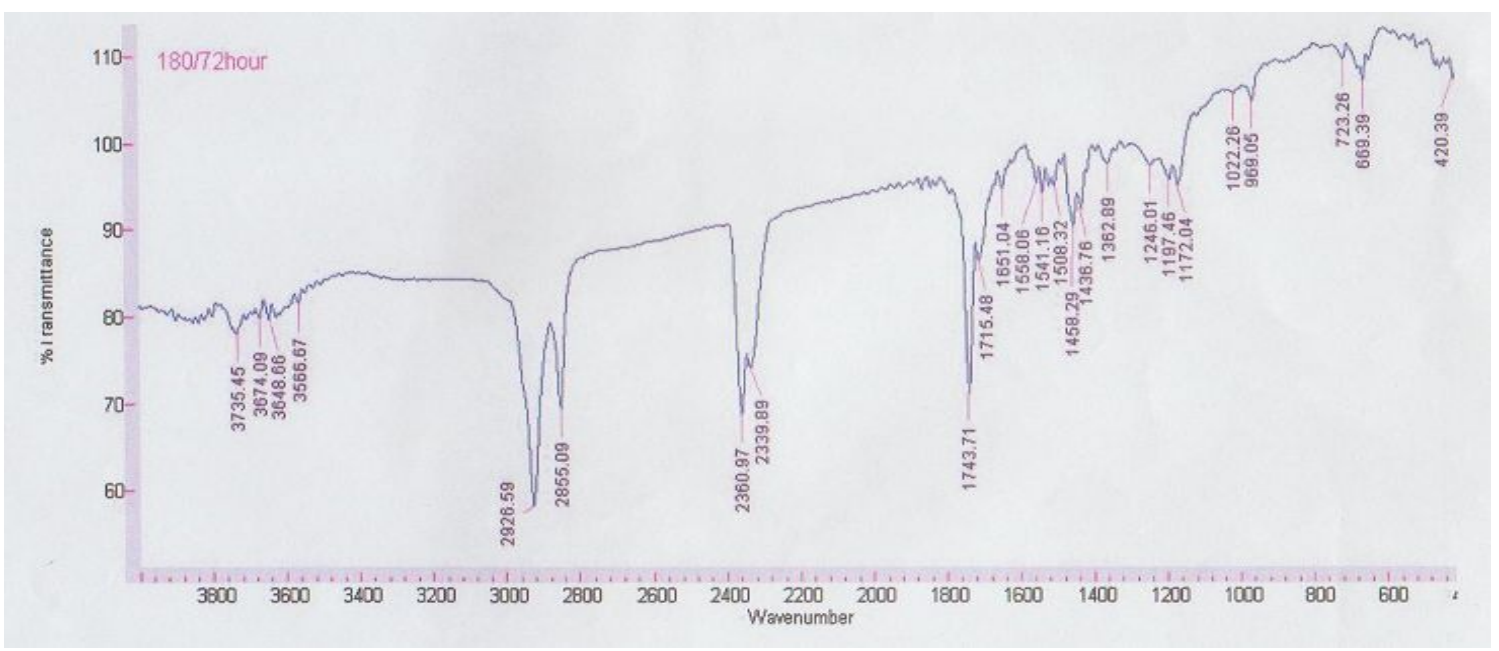

Gambar 10. Analisis gugus sulfonat pada hasil degradasi MES dari metil ester jarak pagar yang dipanaskan pada suhu $180^{\circ} \mathrm{C}$ selama 72 jam yang diuji dengan menggunakan FTIR.

Perubahan Komposisi Metil Ester Hasil Degradasi Termal pada MES Berbasis Minyak Jarak Pagar

Hasil thermal degradasi pada MES dari minyak jarak pagar menunjukkan terjadi perubahan komposisi senyawa asam lemak.
Gambar 11 adalah kromatogram MES dari minyak jarak pagar sebelum dipanaskan sedangkan Gambar 12, 13 dan 14 adalah kromatogram MES yang sudah dipanaskan pada berbagai perlakuan dan Tabel 1 adalah hasil dari pemecahan MES pada berbagai perlakuan.

Tabel 1. Perubahan yang terjadi akibat thermal degradasi pada MES dari jarak pagar.

\begin{tabular}{|c|c|c|c|c|c|c|c|}
\hline \multirow{2}{*}{ Komponen } & \multicolumn{7}{|c|}{ Kadar (\%) } \\
\hline & MES & $\mathrm{A}$ & $\mathrm{B}$ & $\mathrm{C}$ & $\mathrm{D}$ & $E$ & $\mathrm{~F}$ \\
\hline ME kaproat & & & & & 0,28 & 0,26 & 0,28 \\
\hline ME palmitat & 7,99 & 6,68 & 6,73 & 6,81 & 6,73 & 6,36 & 6,88 \\
\hline ME Palmitoleat & 0,44 & - & 0,29 & 0,26 & 0,20 & 0,24 & \\
\hline ME stearat & 3,99 & 3,46 & 3,53 & 3,68 & 3,71 & 3,53 & 3,82 \\
\hline ME Elaidat & 0,79 & 0,51 & 0,51 & 1,16 & 5,78 & 3,39 & 12,01 \\
\hline ME Oleat & 24,51 & 19,22 & 18,96 & 18,62 & 14,43 & 15,15 & 9,32 \\
\hline ME linoleidat & - & - & - & - & 2,35 & 0,77 & 4,10 \\
\hline ME Linoleat & 18,55 & 7,76 & 7,53 & 6,30 & 1,86 & 3,12 & 0,5 \\
\hline
\end{tabular}

Keterangan:

$\mathrm{A}=$ perlakuan MES jarak pagar pada suhu pemanasan $100^{\circ} \mathrm{C}$, waktu 8 jam

$\mathrm{B}=$ perlakuan MES jarak pagar pada suhu pemanasan $100^{\circ} \mathrm{C}$, waktu 72 jam

$\mathrm{C}=$ perlakuan MES jarak pagar pada suhu pemanasan $150^{\circ} \mathrm{C}$, waktu 8 jam

$\mathrm{D}=$ perlakuan MES jarak pagar pada suhu pemanasan $150^{\circ} \mathrm{C}$, waktu 72 jam

$\mathrm{E}=$ perlakuan MES jarak pagar pada suhu pemanasan $180^{\circ} \mathrm{C}$, waktu 8 jam

$\mathrm{F}=$ perlakuan MES jarak pagar pada suhu pemanasan $180^{\circ} \mathrm{C}$, waktu $72 \mathrm{jam}$ 


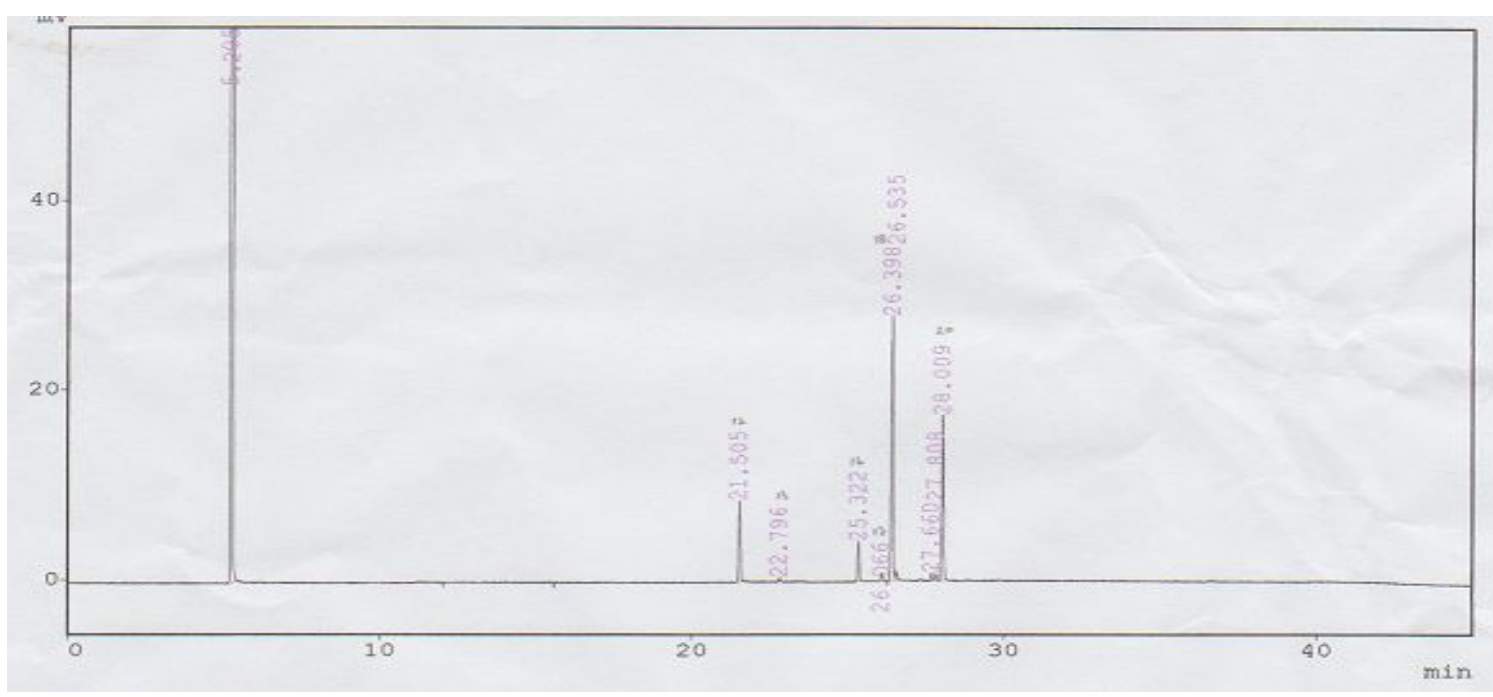

Gambar 11. Kromatogram komposisi metil ester dari MES jarak pagar dengan menggunakan kromatografi gas.

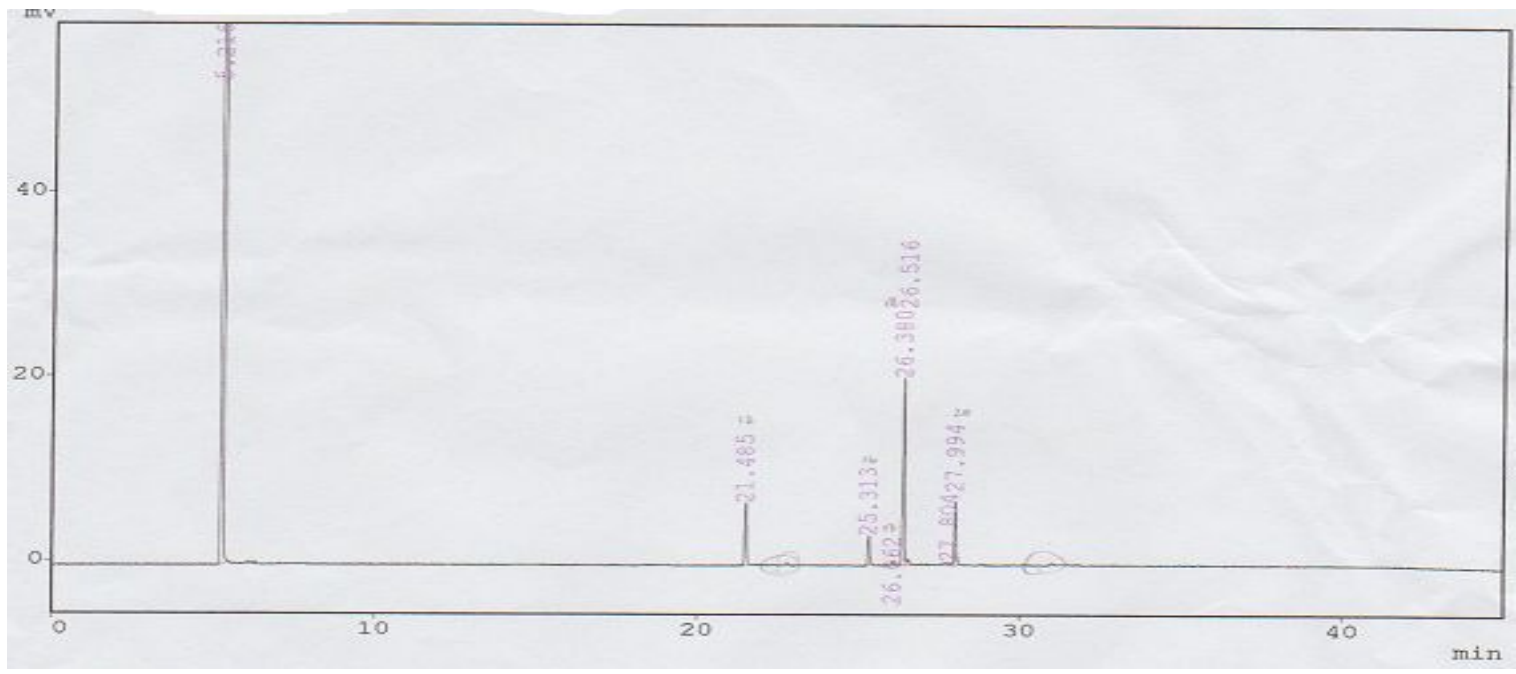

Gambar 12. Kromatogram komposisi metil ester dari MES jarak pagar dengan suhu pemanasan $100^{\circ} \mathrm{C}$, waktu 8 jam. 


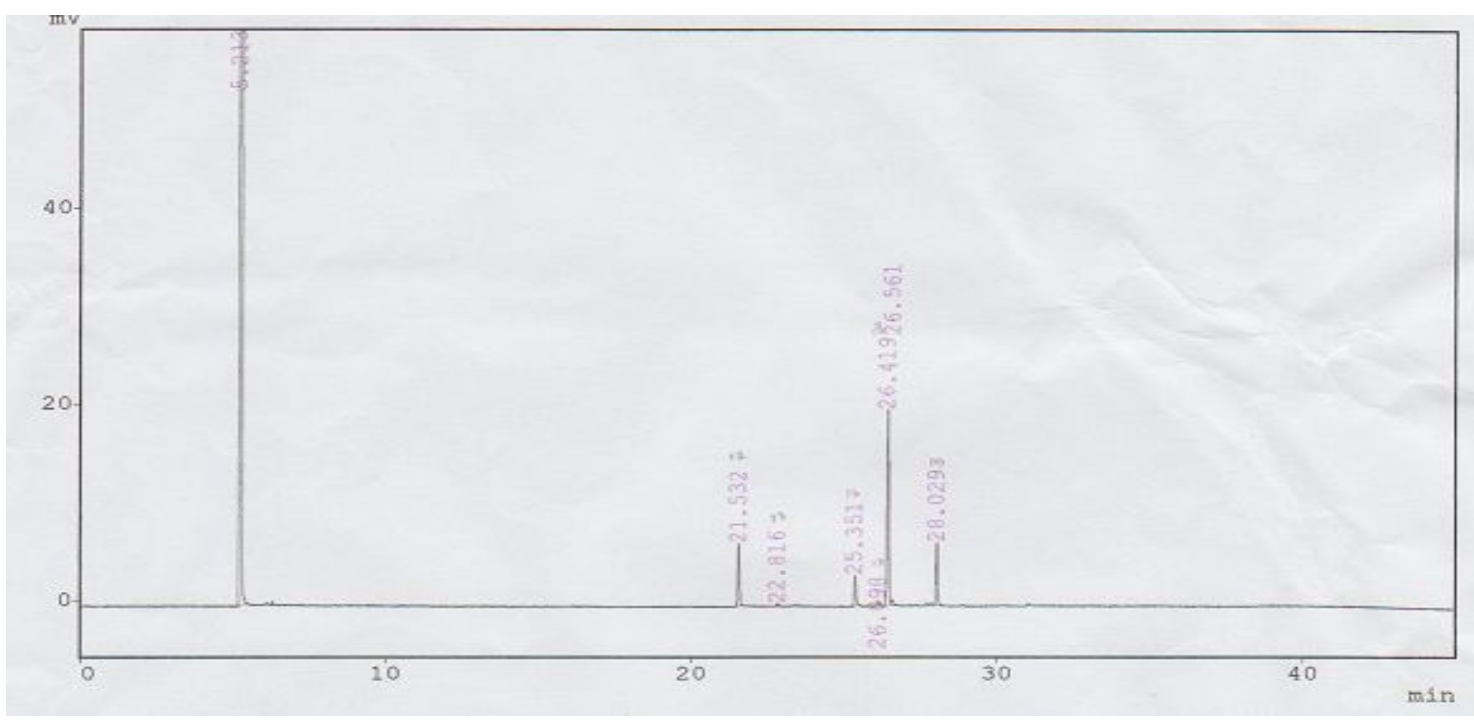

Gambar 13. Kromatogram komposisi metil ester dari MES jarak pagar dengan suhu pemanasan $100{ }^{\circ} \mathrm{C}$, waktu 72 jam.

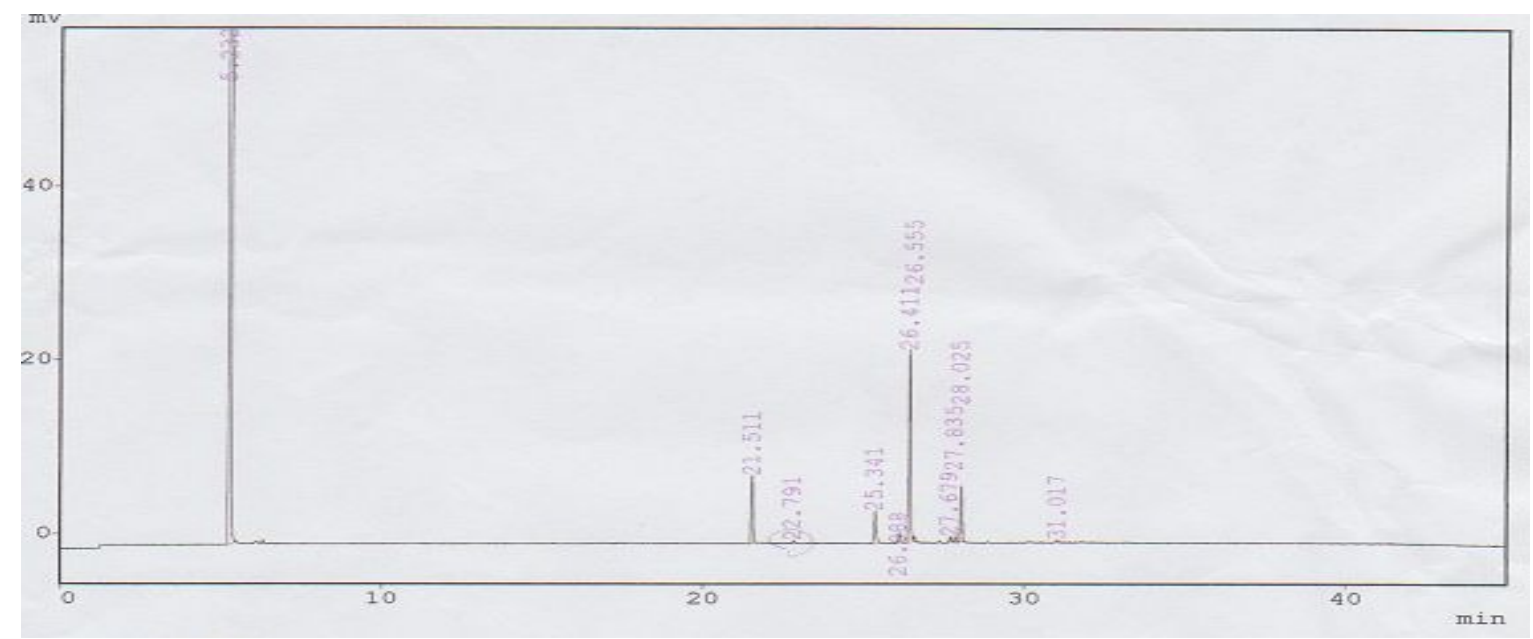

Gambar 14. Kromatogram komposisi metil ester dari MES jarak pagar dengan suhu pemanasan $150^{\circ} \mathrm{C}$, waktu 8 jam.

Metil ester dari jarak pagar memiliki kandungan asam lemak tidak jenuh yang cukup tinggi yaitu metil oleat $77,05 \%$ dan metil palmitat $14,6 \%$, laurat $0,024 \%$, miristat $0,066 \%$ dan stearat $0,146 \%[23]$. Umumnya kerusakan oksidasi terjadi pada asam lemak dengan derajat ketidakjenuhan yang tinggi, tetapi bila minyak dipanaskan pada suhu 100 ${ }^{\circ} \mathrm{C}$ atau lebih, asam lemak jenuh dapat juga teroksidasi ${ }^{[24]}$. Proses kerusakan minyak dapat terjadi karena pemanasan yang mengakibatkan perubahan susunan kimiawi karena penguraian trigliserida menjadi gliserol dan asam-asam lemak ${ }^{[25]}$. Pada perlakuan suhu $100{ }^{\circ} \mathrm{C}$ pada waktu pemanasan 8 dan 72 jam terjadi penurunan yang cukup tajam pada asam lemak oleat dan linoleat sedangkan pada perlakuan suhu $150^{\circ} \mathrm{C}$ dan suhu $180^{\circ} \mathrm{C}$ selama waktu 8 dan 72 jam mulai terbentuk asam kaproat dengan berat molekul yang lebih rendah dan terjadi peningkatan asam jenuh seperti palmitat, stearat dan terjadi pembentukan trans dari cis oleat yaitu asam elaidat pada suhu 150 ${ }^{\circ} \mathrm{C}$ selama 72 jam dan $180{ }^{\circ} \mathrm{C}$ selama waktu 8 dan 72 .

Isomer geometris terbentuk apabila ikatan cis terisomerisasi menjadi konfigurasi trans yang secara termodinamik sifatnya lebih stabil daripada cis, seperti asam oleat menjadi 
elaidat. Jumlah asam lemak trans (elaidat) semakin meningkat dengan penambahan waktu pemanasan ${ }^{[26]}$. Penurunan yang paling tajam terjadi pada asam linoleat dibandingkan dengan asam oleat. Menurut Damodaran et $a l^{[27]}$ asam linoleat memiliki 10 sampai 40 kali lebih cepat teroksidasi dibandingkan asam oleat. Hasil oksidasi asam linoleat adalah campuran konjugasi antara 9- dan 13-diene hyroperoxides kemudian mengalami bentuk geometrik membentuk trans isomer yaitu asam linolelaidat yang makin meningkat dengan peningkatan suhu perlakuan. Asam ini belum terbentuk pada suhu 100 dan $150{ }^{\circ} \mathrm{C}$ selam 8 jam pemanasan, tetapi setelah pemanasan 72 jam mulai terbentuk senyawa trans tersebut. Cristie $^{[28]}$ melaporkan bahwa linseed oil yang mengandung asam lemak tidak jenuh yang tinggi akan mengalami oksidasi yang lebih cepat dibandingkan minyak olive yang lebih sedikit minyak tidak jenuhnya. Peningkatan suhu dan lama waktu yang lama akan meningkatkan laju oksidasi dan kerusakan pada komposisi metil ester sehingga terbentuk hasil oksidasi berupa senyawa yang memiliki berat molekul lebih rendah dan terjadi penjenuhan pada ikatan rangkap. Hal tersebut ditandai dengan menurunnya jumlah metil ester yan memiliki ikatan rangkap seperti pada metil oleat dan linoleat.

\section{KESIMPULAN}

Semakin tinggi dan lama suhu pemanasan akan merusak gugus sulfonat dari MES jarak pagar. Pemanasan pada suhu $180{ }^{\circ} \mathrm{C}$ selama 72 jam menurunkan gugus fungsi sulfonat dan terjadi perubahan komposisi metil ester asam lemak menjadi terdegradasi menjadi metil ester yaitu dari cis menjadi bentuk trans. Peningkatan suhu akan menurunkan bilangan iod, bilangan asam dan stabilitas emulsi tetapi meningkatkan nilai tegangan permukaan.

\section{DAFTAR PUSTAKA}

1. Unisource Canada, GLOSSARY. Unisource Canada, Inc, 2005. http://www.unisource.ca/upload/tools/facility supply glossary en_g.pdf, 30/11/2006

2. L. L. Schramm, E. N. Stasiuk, H. Yarranton, B. B. Maini, and B.
Shelfantook, Tempe-rature effects in the conditioning and flotation of bitumen from oil sands in terms of oil recovery and physical properties, Petroleum SocietyCanadian Institute of Mining, Metallurgy \& Petroleum, Paper., 2002-074, www.ucalgary.ca/ schramm/CIPC_2002_074.pdf 15/03/2006

3. V. A. Hackley and C. F. Ferraris, The use of nomenclature in dispersion science and technology, national institute of standards and technology: special publication 960-3, U.S, Government Printing Office, Washington, 2001, www.nist.gov/public affairs/practiceguidesember/SP9603.pdf, $17 / 03 / 2006$

4. J. L. Salager, Surfactants types and uses, version 2. FIRP Booklet \# E300-A: Teaching Aid in Surfactant Science \& Engineering in English, Universidad De Los Andes, Mérida-Venezuela, 2002, http: //www.firp.ula.ve/cuadernos/E300A pdf, 20/03/2005

5. Particle Engineering Research Center, Surfactants, Univ. of Florida, www.unmc. edu/pharmacy/wwwcourse/p_surfactants_0 0_files/p_surfactants.ppt, 20/11/2005

6. W. H. D. Groot, Sulphonation technology in the detergent house, Kluwer Academic Publisher, Netherland, 1991.

7. Y.H. Hui, Bailey's Industrial Oil and Fat Products, 5th Edition Vol. 5, John Willey \& Sons, Inc, New York.7, 1996.

8. K. L. Matheson, Formulation of household and industrial detergent, in: soap and detergent: a theoretical and practical review, Splitz, L (ed). AOCS Press, Champaign, Illinois, 1996.

9. P. C. Hui and M. E Tuvell, a Mechanistic approach to the thermal degradation of $\alpha$ olefin sulfonates, JAOCS., 65(6), 1988.

10. P. Zhao, Development of high performance surfactant for difficult oil, Thesis The University of Texas at Austin, 122, (2007).

11. V. M. Zigler and L. L. Handy, Effect of temperature on surfactant adsorbsiin porous media, Journal Soc, Pet, Eng., 218228, (1981).

12. S. Hidayati, Perancangan proses produksi metil ester sulfonat dari minyak sawit inti sawit dan uji efektivitasnya untuk pendesakan minyak bumi, 2006. 
13. American Society for Testing and Material (ASTM), Annual Book of ASTM Standards: Soap and Other Detergents, Polishes, Leather, Resilient Floor Covering, Baltimore: ASTM, 2001.

14. AOAC, Official Method of Analysis of the Association of Official Analytical Chemist, AOAC, Washington, 1995.

15. M. H. S. Ginting dan N. Herlina, Tegangan Permukaan cairan dengan metode drop out dan metode buble. USY Digital Library, 2002.

16. Foster et all, Sulfonation and sulfation process. The Chemithon Corporation.

17. R. A. Williams and S. J. R Simon, Handling colloidal material in colloid and surface engineering application in process industries, Oxford: Bitterworth-Heinemann Ltd, 1992.

18. K. Sutriah, T. T. Irawadi, M. Farid, M. Khotib, B. M. Soebrata, dan H. Purwaningsih, Sintesis dan pencirian surfaktan berbasis minyak sawit dan karbohidrat untuk aditif produk pangan dan detergen, Prosiding Seminar Nasional Himpunan Kimia Indonesia, IPB Bogor, 259-270, (2006).

19. R. L. Peesok, Shields, T. Coumrns, and M. William, Modern Method of Chemical Analysis, Edisi ke-2, New York: John Willey \& Sons, Inc, 1976.

20. R. M. Silverstein and F. X Webster, Spectrometric Identification Organic Compound, John Willey \& Sons, Inc, New York, 1988.

21. F. A. Russin, F. R V. Voor and J. Sedman, Novel method to rapid monitoring of lipid oxidation by FTIR spectroscopy using disposable IR Card. JAOCS, 80(7): 202208, (2003).

22. J. Samuelsson and M. Johansson, Oxidation of FA with alkana or alkyl functionalities studied with chemiluminescence and real time IR Spectroscopy, JAOCS, 80(5): 491-496, (2003).

23. R. Edison dan S. Hidayati, Production surfactant methyl ester sulfonate (MES) of jatropha oil (Jatropha Curcas L.) with temperature and time sulfonation, temperature purification, and concentration methanol settings, Proceeding International Seminar on Sustainable Biomass Production and Utilization Challenges and Oppor-tunities (ISOMASS) August, 3-4, 2009.

24. F. Riyanti, P. Loekitowati, dan R. Muharran, Pengaruh pemanasan dan penambahan antioksidan bht pada minyak biji ketapang dan kinetika reaksi oksidasi, Seminar Nasional Sains IV, 2011.

25. R. Aminah, Pengaruh pemanasan pada minyak goreng yang diobservasi pada tikus putih. pusat penelitian penyakit tidak menular, Badan Penelitian dan Pengembangan Kesehatan Dep. Kes. RI, Jakarta, 2002.

26. R. A. D. Sartika, Pengaruh suhu dan lama proses menggoreng (deep friyng) terhadap pembentukan asam lemak trans. Makara Sains., 13(1): 23-28, 2009.

27. S, K. L. D. Parkin and O. R. Fennema, Fennema's Food Chemistry. Fourt Edition. CRC Press, New York, 2007.

28. W. W. Cristie, Triacylglycerols-structure, composition and analysis. The lipid Library, 2004. 
